\title{
TOPOGRAPHICAL PICTURE OF DIGIT OSSIFICATION IN THE SHEEP IN THE LATE EMBRYONIC AND EARLY FOETAL PERIOD OF DEVELOPMENT
}

\author{
H. CERNÝ \\ Department of Anatomy, Histology and Embryology, University of Veterinary Science, 61242 \\ Brno
}

Received March 30, 1989

\begin{abstract}
Cerný H.: Topographical Picture of Digit Ossification in the Sheep in the Late Embryonic and Early Foetal Period of Development. Acta vet. Brno, 59, 1990: 91 -99.

Using a model of acropodium skeleton of three embryos (CRL 18-35 mm) and 26 foetuses (CRL $41-210 \mathrm{~mm}$ ) of Merino sheep we studied the development of the skeleton of digits during the late embryonic and early foetal period of ontogeny using light microscopy.

The material was processed by standard methods for the study of histological sections. These were stained with hematoxylin-eosin, van Gieson and alcian blue, together with a mixture of Ponceau $2 \mathbf{R}-$ acid fuchsine.

From the histotopographical point of view we described the structural picture of the developing acropodium skeleton in relation with the foetal age and morphological determination of individual phases of ossification. We confirmed the sequence of ossification of digits III and IV. The distal phalanx is the first to ossify, followed by the proximal and then middle phalanges.

Ossification takes place at the age of 47 to 70 days of prenatal development. It begins on the 47th day with desmogenous ossification of the tip of the distal phalanx, progressing proximally and joining the endochondral ossification of the cartilaginous skeleton of the cartilaginous skeleton of the corpus.

The onset of ossification of the cartilaginous skeleton of diaphyses of the proximal and middle phalanges takes place on axial facets and progresses abaxially.

From the 80th day we can notice marked proliferation of blood vessels to the skeleton of epiphyses and distal capitula of the proximal and middle phalanges. The spreading blood capillaries cause disintegration of cartilage, form numerous canals holding osteogenous mesenchyma besides the vessels. Capitula of both phalanges ossify from the diaphysis.
\end{abstract}

Sheep, prenatal ontogeny, ossification of phalanges

The cartilaginous embryonic skeleton, which subsequently ossifies to form a definitive skeleton, comes into being in the transformation of the prechondral into chondral blastema. The complexity of the process of osteogeny is conditioned by the differentiation and growth of the structure in the course of ontogenetic development.

Available literary references show that sheep skeleton was a frequent subject of investigation in the past. A number of authors contributed to general knowledge of the cartilaginous skeleton, its development and growth from the point of view of its morphology or function in relation to its prenatal as well as postnatal ontogeny.

Although the development of the sheep foetal skeleton was described by Harris (1937), Benzie (1950), Smith (1956), Las celles (1958), Rajtová (1972, 1973), more recently by Neiss (1982) and Cerný (1987) with a large number of detailed information, there is still enough room for a detailed description of ossification in individual developmental periods in view of the step-like character of this process, and histotopographical identification.

We therefore decided to use the model of sheep acropodium to study the dynamics of changes in the morphological picture of ossification in the period of early foetal ontogeny. 
Table 1

Age and Number of Embryos and Foetuses Used

\begin{tabular}{|c|c|c|c|l|}
\hline No. & CRL (mm) & $\begin{array}{c}\text { Days after } \\
\text { Fertilization }\end{array}$ & $\begin{array}{c}\text { Number of } \\
\text { Individuals }\end{array}$ & Stage of Ontogeny \\
\hline 1 & 18 & - & 1 & late \\
2 & 25 & - & 1 & embryonic \\
period
\end{tabular}

\section{Materials and Methods}

A total of three embryos (CRL $18-35 \mathrm{~mm}$ ) and 26 foetuses (CRL $41-210 \mathrm{~mm}$ ) of Merino sheep whose age was determined according to Evans and Sack (1973) was used for the study of the development of the acropodium skeleton in the sheep.

The material was fixed in $10 \%$ formol and processed in a standard manner for light microscopy. Frontal, sagittal and horizontal sections made of tissue paraffin or celloidin blocks were stained with hematoxylin-eosin, van Gieson, alcian blue and a mixture of Ponceau $2 \mathrm{R}$ and acid fuchsine.

\section{Results}

In the embryo of CRL $18 \mathrm{~mm}$, the laminae of the hand and foot are clearly discernible (Fig. 2). Laminae are bowl-shaped, with the palmar and plantar facets slightly concave. The edges of the two laminae feature delicate indentation, shallow nicks between teeth marking the boundary between individual primordia. These are formed by prechondral cellular blastema (Fig. 1), between principal primordia of digit III and IV marked reduction of mesenchyma and formation of blood vessels can be observed (Fig. 1). Clearly discernible at this time are also reduced primordia of digits II and V all Figures are placed at the end of the volume.

In the next period in embryo of CRL $25 \mathrm{~mm}$ the change of the prechondral blastema into chondral blastema is taking place in the lamina of the hand with the formation of embryonal cartilage.

Also foot lamina contains digit primordia formed by prechondral blastema with gradual chondrogeny.

Hand and foot laminae in the embryo of CRL $35 \mathrm{~mm}$ are characterized by a cut between principal primordia and the lamina as a whole becomes elongated. Development of principal primordia takes place, primordia of digits II and V are disproportionally smaller. The main part of the digit skeleton (phalanx proximalis and media) is already formed by embryonal cartilage, the corpus of the distal phalanx passing through the stage of differentiation of chondral blastema. Individual phalanx skeletons are separated from each other by narrow gaps containing in their central parts condensed material of the original mesenchymal blastema. 
The appearance of joint cavities of digit joints can be observed, which came into being through the reduction of the blastema material.

In the foetus of CRL $60 \mathrm{~mm}$ (47 days), hypertrophy of the cartilage of the distal phalanx and desmogenous ossification of the tip have begun (Fig. 3). Phalanx media and proximalis are formed by normal cartilage at this stage. The above description applies to the thoracic as well as the pelvic limbs.

The period of CRL $108 \mathrm{~mm}$ (60 days) is characterized by gradual ossification of phalanges beginning with the phalanx distalis, then phalanx proximalis and media. The apex of the distal phalanx is markedly ossified, cortical lamellae appear, the perichondrium differentiates, the activity of the osteogenous blastema at the tip increases, and the surrounding cartilage is becoming hypertrophic.

Thin lamellae of the cortical bone appear on the surface of the corpus of phalanx proximalis as a result of the activity of perichondrium, and later periosteum. In the central part of the phalanx, endochondral ossification is taking place, while in the proximal part a continuous cartilage of the skeleton is being formed. In the epiphyseal skeleton, numerous canals occur proximally that contain blood vessels and cellular osteogenous material.

The last of the phalanges to ossify is the phalanx media. On the axial area of its corpus we can find the initial stage of the primary ossification centre which is manifested by hypertrophy of chondrocytes and metachromasia of the ground matter of the hypertrophic cartilage. A more detailed investigation shows a gradual invasion of cellular osteogenous elements into the centre. The cells are derivatives of the osteogenous layer of the perichondrium. In view of the fact that at this stage the structure of the ossification centre shows no mineralization, radiographic imaging is not possible.

The onset of the osteogenous phase, however, comes very soon because at the next stage, i. e. 10 days later in the foetus of CRL $150 \mathrm{~mm}$ (70 days), the middle part of the phalanx is completely ossified. Documents from this period show that ossification begins axially and progresses in the abaxial direction (Fig. 10). On the axial area, a thin edge of cortical bone due to periosteal ossification appears. Perichondrium in this area differentiates completely into periosteum (Fig. 11).

Light microscopy shows that ossification of the tip of the distal phalanx continues together with the differentiation of the periosteum and the endochondral ossification of its corpus. Further development of endochondral ossification can also be demonstrated in the proximal phalanx.

In foetuses of CRL $210 \mathrm{~mm}$ ( 80 days) the diaphyses of the proximal and middle phalanges are completely ossified, individual beams of the spongious bone form a compact anastomosing system. The medullary cavity is usually only hinted at in the central parts of diaphyses. Because these are monoepiphyseal bones, the epiphysodiaphyseal, boundary is formed only in proximal parts of of the bone. Distal capitula of both phalanges ossify in later developmental stages from the diaphysis. In this period, however, capitula are completely made up of cartilage.

Contrary to the cylindrical shape of proximal and middle phalanges, the distal phalanx is markedly conical. Its skeleton is formed by cartilage, which arches in a prominent skeleton of the processus extensorius at the dorsal crown-shaped edge. The corpus and apex are formed by beams of a spongy bone, which are mainly formed by periosteal ossification (Figs. 7, 8). Differentiation of osteogenous cells and their secretion activity lead to the formation of new bone tissue, attached to the surface of the cortical bone. The cortical bone is interrupted with communication to intertrabecular space. Osteogenous cellular material of the periosteum 
penetrates to the centre of the skeleton both independently and with blood vessels, where it differentiates into cellular elements of bone marrow. The apex phalangis distalis, just as the distal part of the corpus, originates from the osteogenous mesenchymal blastema. First, the woven bone is formed, which is then restructured into a definitive bony apex.

In epiphyseal cartilages, as well as in distal capitula of the cartilaginous model, we can observe numerous osteogenous canals (Fig. 12) which contain blood vessels and abundant cellular material. In the case of hypophyses, this osteogenous cellular material comes from perichondrium or periosteum, its basic cell is the fibroblast which in subsequent stages of ossification differentiates into a cellular element with a significant osteogenous potential - the osteoblast.

On the other hand, capitula are penetrated by osteogenous cells from the forming primary cavity of the ossifying diaphysis. The cellular material filling central parts of the diaphysis undergoes differentiation into osteogenous cells and cellular elements of the medulla (Figs. 12, 13, 14).

From the viewpoint of morphology, the existence of blood vessels with pericapillary cells in the proliferative and hypertrophic zone of the ossifying cartilage (Fig. 15) and vessels penetrating from the epiphyseal perichondrium transchondrally to the diaphyseal region can be considered an interesting finding. In this respect, we noted isolated cases of blood vessels penetrating from the proliferative zone of the cartilage as far as the osteoid zone of endochondral ossification.

Morphological picture of the developmental stage studied manifests a pronounced proliferation of blood vessels and cellular elements to cartilages of epiphyses and cartilaginous skeletons of capitula of the proximal and middle phalanges. It was here that we observed penetrating blood capillaries accompanied with pericapillary cells. They were medullar capillaries of the diaphysis which invade the capitulum cartilage and initiate its gradual ossification and the appearance of the subchondral bone. The original skeleton is reduced to articular cartilage.

\section{Discussion}

The development of appendicular skeleton! takes place in four stages. In the late embryonal period, a conversion of prechondral mesenchymal skeleton into cartilaginous embryonal skeleton takes place. Osteogeny proper begins with the appearance of primary ossification centres in diaphyses of cartilaginous skeletons. The third stage is characterized by the appearance of secondary ossification centres, ossification of epiphyses and the formation of epiphysodiaphysary lamellae. And finally the fourth stage is connected with the ossification of epiphyseal plate and the appearance of the definitive skeleton.

The first two stages take place in the prenatal period, the third is a transitory stage between the pre- and postnatal development, and the fourth stage is linked with the postnatal period of development. Our observations concern the morphological picture of the first two stages and partially also the third.

Ossification is a complex process of development taking place in phases, connected with tissue mineralization. Gradual mineralization of the basic bone tissue material increases its density and allows its radiographic imaging. An advanced degree of mineralization is an necessary condition for the use of the radiographical method.

In early stages of ossification of the cartilaginous foetal skeleton, important 
Table 2

Topographical Picture of Ossification Related to the Age of Embryo and Foetus

\begin{tabular}{|c|c|c|c|}
\hline $\begin{array}{c}\text { Digit Skeleton } \\
\text { Development }\end{array}$ & $\begin{array}{c}\text { Embryo } \\
(\mathrm{CRL} \\
\mathrm{mm})\end{array}$ & $\begin{array}{l}\text { Foetus } \\
\text { (CRL } \\
\mathrm{mm})\end{array}$ & Histotopography \\
\hline $\begin{array}{l}\text { Mesenchymal/prechondral skeleton } \\
\text { Transformation of mesenchymal } \\
\text { skeleton } \\
\text { into chondral skeleton cartilaginous } \\
\text { embryonal skeleton formation }\end{array}$ & $\begin{array}{l}18 \\
25 \\
35\end{array}$ & & $\begin{array}{l}\text { hand and foot laminae } \\
\text { hand and foot laminae } \\
\text { cartilaginous phalanges }\end{array}$ \\
\hline $\begin{array}{l}\text { Ossification of cartilaginous skeleton, } \\
\text { individual phalanges } \\
\text { 1. Phalanx distalis } \\
\text { hypertrophy of the corpus cartilage } \\
\text { osteogenous mesenchymal blastema } \\
\text { desmogenous ossification } \\
\text { periosteal ossification } \\
\text { osteogenous activity of mesenchymal } \\
\text { blastema } \\
\text { periosteal ossification } \\
\text { 2. Phalanx proximalis } \\
\text { periosteal ossification, cortical la- } \\
\text { mella formation, endochondral ossi- } \\
\text { fication } \\
\text { 3. Phalanx media } \\
\text { formation of primary ossification } \\
\text { centre } \\
\text { peri- and endochondral ossification } \\
\text { progressing ossification }\end{array}$ & & $\begin{array}{r}60 \\
60 \\
\\
70 \\
70 \\
\\
108 \\
108 \\
\\
210\end{array}$ & $\begin{array}{l}\text { corpus phalang. dist. } \\
\text { its appearance on apex phalangis } \\
\text { dist. } \\
\text { apex phalang. dist. } \\
\text { corpus phalang. dist. } \\
\text { ossification of apex } \\
\text { initial ossification, corpus pha- } \\
\text { lang. dist. } \\
\text { progressing ossif. of corpus pha- } \\
\text { lang. dist. } \\
\text { diaphysis } \\
\text { ossification of diaphysis comple- } \\
\text { ted, primary medullar cavity } \\
\text { delineated } \\
\text { axial facet of cart. diaphysis } \\
\text { diaphysis of middle phalanx } \\
\text { complete ossification of diaphy- } \\
\text { sis, primary cavity filled with me- } \\
\text { dullar blastema } \\
\text { cartilag. capitula and epiphyses } \\
\text { of proximal and distal phalanges }\end{array}$ \\
\hline
\end{tabular}

morphological changes of structure take place. In view of insufficient tissue mineralization, radiography cannot be successfully used to study these changes in their full extent. We therefore consider it necessary to employ histological methods to study the situation in the late embryonal and early foetal period using tissue section.

When we look into the relation between the foetal age and the number of ossification centres of the appendicular skeleton, we will conclude that a significant development of the skeleton does not take place before the age of $90-100$ days! 
From this point of view, Lascelles (1958) therofore divides the prenatal development in the sheep into two periods: $37-92$ days and $92-141$ days.

In the first period, structural differentiation mainly predominates, which is clearly discernible histologically. The radiographic method, on the other hand, would not yield unambiguous results, because structure imaging at the beginning of ossification is insufficient.

The other period, from 90 to 100 days of age, is characterized by an absolute increase in the number of ossification centres of the appendicular skeleton, which comes as a result of ossification of epiphyses. This period is further characterized by increased mineralization and general maturation of bone tissue. It is therefore appropriate to use the radiographic method, which not only allows the study of the skeletal development, but also provides the possibility of its further morphometrical and densitometrical investigation.

When we compare our results concerning ossification of the acropodium with literary data, we find some differences not only in the determination of the appearance of ossification centres weith regard to the foetal age, but also in the sequence of ossification of individual phalanges.

Harries (1937) reports that all phalanges on the pelvic and thoracic limbs ossify on the 61st day simultaneously, Lascelles (1959) believes that ossification of the 1st, 2nd and 3rd phalanges takes place in that order between the 59th and 71st day, the thoracic limb being 2 days ahead of the pelvic limb. According to Raj tová (1972), the first and second phalanges ossify from two ossification centres, while the third phalanx from only one. Ossification begins on 47th day in phalanx distalis, the corpus of the proximal phalanx ossifies on the 56th day and on the 58th day an ossification centre appears in the cartilaginous skeleton of the middle phalanx corpus. According to this author, the ossification of epiphyses and thus the formation of secondary ossification centres does not take place before the 145th day. Rajtová (1972) reports the same ossification sequence in individual phalanges as Smith (1956), Neiss (1982) and Černý (1987), while differring with them in time intervals of their ossification. The range reported by Rajtová (1972) is 47th - 58th day, while Harris (1937) puts it on the 61st day. Neiss (1982) claims that the first calcium in the distal phalanx is deposited in the foetus of CRL $67.5 \mathrm{~mm}$, and that mineralization can be constantly demonstrated from the CRL of $71 \mathrm{~mm}$. The CRL reported by Evans and Sack (1973) represents the 48th day of foetal age, the CRL of $71 \mathrm{~mm}$ the 50th day post conceptionem. Ossification of diaphysis of the proximal phalanx begins at $76 \mathrm{~mm}$, occurs regularly at $94 \mathrm{~mm}$, the middle phalanx ossifies at the lenght of $94 \mathrm{~mm}$. In foetuses of CRL of $110 \mathrm{~mm}$, diaphyses of middle phalanges are ossified regularly. According to our previous findings (Černý 1987) as well as our recent observations, the onset of ossification of phalanges III and IV is linked with the period of the 47th to 70th day. It is evident that the histological method of the study of tissue sections can be used a detailed documentation of the preossification stage, when ossification from the structural point of view has already begun but the deposition of mineral substances in the basic cartilaginous material is still insuffcient for radiographical purposes. Our findings show that the beginning of the ossification proper, connected with the mineralization of the basic material occurs in fact between the 50th and 62ad day of prenatal development.

In agreement with other authors, we can report that ossification of the diaphysis of the proximal and middle phalanges always begins in their axial facets and progresses gradually in the abaxial direction. From diaphyses of these phalanges, 
ossification progresses distally, causing ossification of cartilaginous skeletons of capitula. We observed intensive vascular penetration of medullar capillaries from the diaphysis to the capitulum, which not only participates in cartilage resorption but also leads to the appearance of distinct canals in the cartilage which are used by osteogenous cells in their penetration from the primary medullar cavity to the capitulum.

A slightly different type of ossification was observed in the distal phalanx. Its cartilaginous skeleton is not fully replaced with bone tissue. Its apex and distal part of the corpus is formed by desmogenous ossification from osteogenous mesenchymal blastema. The remaining part of the corpus ossifies endochondrally. Ossification progresses proximally, i. e. in the opposite direction than in the case of proximal and middle phalanges.

Our results concerning the time of ossification of phalanges are in closest agreement with the interval proposed by Neiss (1982). As regards their mutual comparison, our results show only insignificant differences with the data pesented by Rajtová (1972).

More substantial are the differences with results of the other authors quoted. These may be caused by breed variability of the material used, or by methods of its processing.

Neiss (1982) also endorses an opinion that any differences that may occur in an interpretation of conclusions concerning sheep skeleton ossification in prenatal ontogeny could be attributed to existing breed differences, which the author considers a kind of intraspecies variability.

\section{Topografický obraz osifikace skeletu prstu ovce v raném fetálním období vývoje}

Na modelu základu akropodia 3 embryí (TK $18-35 \mathrm{~mm}$ ) a 26 fetů (TK 41 až $210 \mathrm{~mm}$ ) ovce plemene Merino jsme v pozdním embryonálním a raném fetálním období ontogeneze studovali v obraze světelného mikroskopu vývoj skeletu prstu.

Materiál jsme zpracovali standartnimi metodikami pro studium histologických řezů, které jsme barvili hemotoxylin - eosinem, van Giesonem a alciánovou modří spolu se směsí Ponceau $2 \mathrm{R}$ - kyselý fuchsin.

$\mathrm{Z}$ histotopografického hlediska jsme popsali strukturální obraz vyvíjejícího se skeletu akropodia $\mathrm{v}$ závislosti na fetálním věku a morfologické determinaci jednotlivých fází osifikace.

Potvrdili jsme pořadí osifikace jednotlivých článků III. a IV. prstu. Nejdříve osifikuje distální článek, následuje proximální a jako poslední osifikuje střední článek.

$\mathrm{K}$ osifikaci dochází v rozmezí 47.-70. dne prenatálního vývoje. Začíná 47 . den desmogenni osifikací hrotu distálního článku, šírí se proximálně a navazuje na enchondrální osifikaci chrupavčitého základu těla.

Počátek osifikace chrupavčitého základu diafýz proximálního a středního článku začíná na axiálních plochách a šírí se abaxiálním směrem.

Od 80. dne pozorujeme výraznou proliferaci krevních cév do základu epifýz a distálních hlavic proximálního a středního článku. Pronikající krevní kapiláry rozrušují chrupavku, vytvářejí četné kanály, kterými probíhá společně s cévami osteogenní mesenchym. Hlavice obou článkủ osifikují z diafýzy. 


\section{Топографическая картина оссификации скелета пальца овцы в ранний внүтриүтробный период развития}

На модели основы акроподия з эмбрионов (ТК 18 - 35 мм) и 26 плодов (ТК 41 - 210 мм) овцы породы мерино на позднем эмбриональном и раннем плодном этапе периода онтогенеза нами проводились исследования развития скелета пальца в изображении светового микроскопа.

Материал обрабатывали стандартными методами для изучения гистологических срезов, окрашивая их гематоксилином - эозином, ван Гизоном и альциановым синим совместно со смесью Понсо 2 P - киспый фиксин.

С гистотопографической точки зрения нами описана структурная картина развивающегося скелета акроподия в зависимости от внутриутробного возраста и морфологического определения отдельных этапов окостенения.

Нами была подтверждена последоватеьность окостенения отдельных фаланг 3 и 4 пальца. Сперва происходит оссификация дистальной фаланги, следует проксимальная и последней оссифицирует средняя фаланга.

Окостенение происходит в переделах 47-70 суток пренатального развития. Начинается она на 47 сутки десмогенной оссификацией кончика дистальной фаланги, распространяясь проксимально, продолжает энхориальным окостенением хрящеватой основы тела.

Начало оссификации хрящеватой основы диафиза проксимальной и средней фаланг происходит на аксиальных поверхностях, распространяясь в абаксиальном направлении.

Начиная с 80 суток можно наблюдать сүщественную пролиферацию кровяных сосудов в основание эпифизов и дистальных головок проксимальной и средней фаланг. Проникающие кровеносные капилляры разрушают хрящ, образуя многочисленные канальцы, которыми совместно с сосудами проходит остеогенная мезенхима. Головки обеих фаланг оссифицируют от диафиза.

I am grafetul to Mrs. A. Hloušková and Mrs. R. Spěšná for the preparation of histolegical preparations and other technical assistance.

\section{References}

BENZIE, D.: Growth of the skeleton of the foetal sheep. Brit. Vet. J. 106, 1950: 231-234

CERNÝ, H.: Structural evaluation of the cartilage and bone tissue in cattle from the functional and morphological aspects. Acta vet. Brno, 49, 1980: 127-144

ČERNÝ, H.: Ossifizierung des Meta- und Akropodiums im Laufe der frühen fötalen Cntogenese beim Schaf. Schweiz. Arch. Tierheilk. 129, 1987: 389-397

EVANS, H. E.-SACK, W. O.: Prenatal Development of Domestic and Laboratory Mammals. Anat., Histol., Embryol., 2, 1973; 11-45

GREEN, W. W.: Comparative growth of the sheep and bovine animal during prenatal life. Am. J. Vet. Res. 7, 1946: 395-402

HARRIS, H.: The foetal growth of sheep. J. Anat., 71, 1937: 516-527

KOLDA, J.: Srovnávací anatomie zviřat domácích. II. Nauka o kostech a chrupavkách. Novina, Brno, 1936, 914 p.

LASCELLES, A. K.: The time of appearance of ossification in the Peppin-type Merino. Aust. J. Zool., 7, 1959: 79-86 
NEISS, W. F.: Zur Ossification des Schafskelettes. Gegenbaurs Morph Jahrb., 128, 1982: 41-57 RAJTOVÁ, V: Úber die Entwicklung des Skelets bei Schaf und Ziege. I. Osteogenesis der Vorderextremität. Gegenbaurs. Morph. Jahrb., 118, 1972 b: 577-588

RAJTOVÁ, V.: Ưber die Entwicklung des Skelets bei Schaf und Ziege. II. Osteogenesis der Hinterextremität. Gegenbaurs. Morph. Jahrb., 119, 1973; 76-85

STARCK, D.: Vergeichende Anatomie der Wirbeltiere auf evolutionsbiologischer Grundlage. Band 2: Das Skeletsystem. Springer Verlag, Berlin, Heidelberg, New York, 1979, 776 p. 


\section{Plate I.}

Černý H.: Topographical Picture ...pp. 91-99.
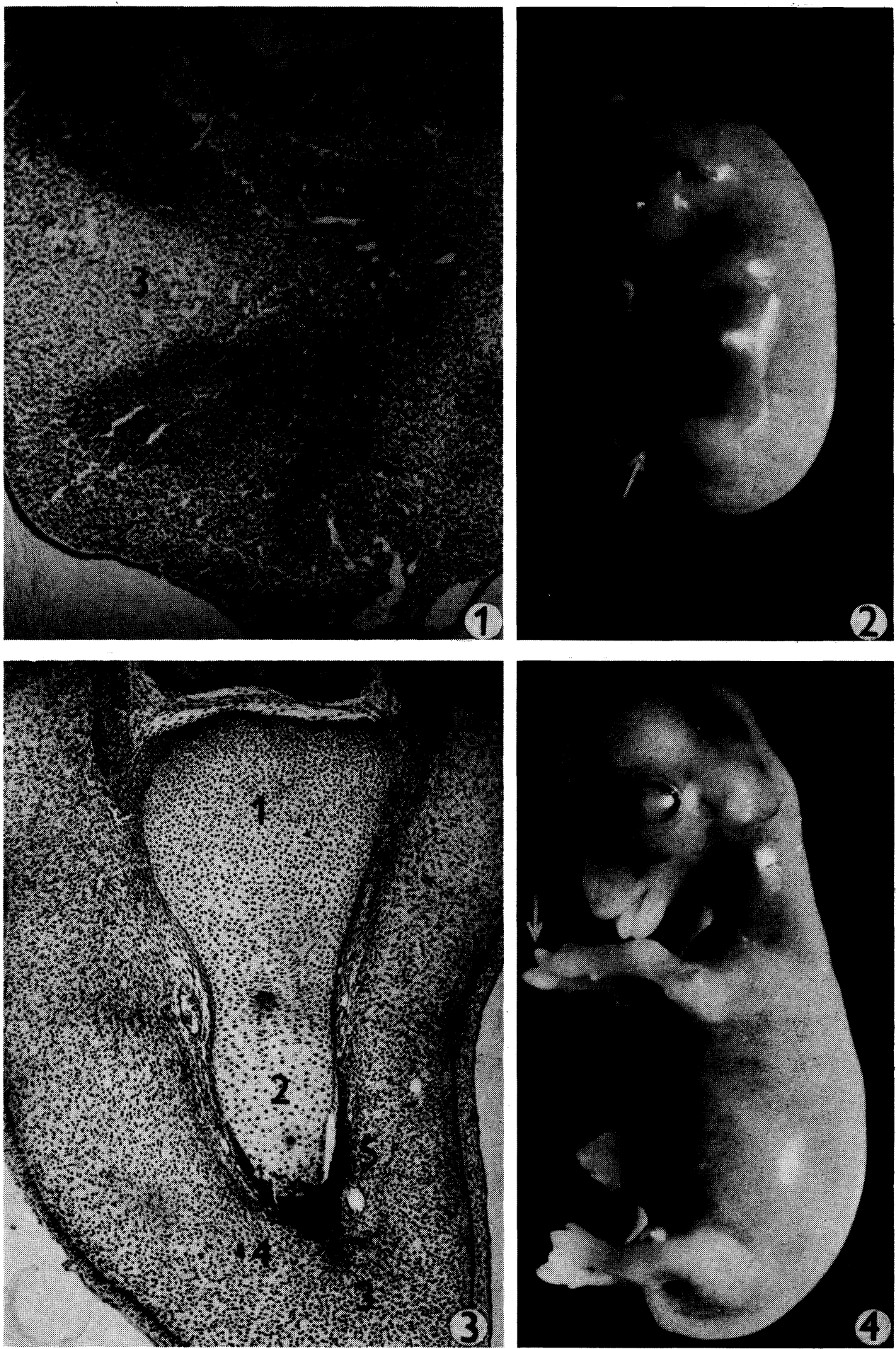


\section{Plate I.}

Figs. 1, 2: Embryo, CRL $18 \mathrm{~mm}$. Prechondral mesenchymal blastema in foot plate. 1 - primordium III, 2 - primordium IV, 3 - reduction of the mesenchyma in future interdigital crevices with the formation of blood vessels. HE, mag. $3.2 \times 4$, embryo mag. $3.5 x$

Figs. 3, 4: Foetus, CRL $60 \mathrm{~mm}$. Initial ossification of the distal phalanx. 1 - cartilaginous skeleton of the phalanx dist, 2 - hypertrophic cartilage on the apex, 3 - osteogenous mesenchymal blastema, 4 - osteoblasts with osteoid basic material, 5 - bony apex, beginning of surface lamella formation, van Gieson, magn. 10x8, foetus magn. $1.5 \mathrm{x}$

Plate II.

Fig. 5: Foetus, CRL $150 \mathrm{~mm}$. Ossification of distal phalanges. 1 - cartilaginous skeleton, 2 - endochondral ossification of phalanx corpus, 3 - apex resulting from desmogenous ossification, 4 - osteogenous mesenchyma HE, magn. $4 \times 10$

Fig. 6: Foetus, CRL $150 \mathrm{~mm}$. Ossification of apex phalangis distalis. 1 - mesenchyma, 2 - osteogenous mesenchyma, 3 - bony apex, 4 - differentiating corium, 5 - blood vessel, 6 - epidermis HE, magn. $10 \times 10$

Fig. 7: Foetus, CRL $210 \mathrm{~mm}$, longitudinal section of the phalanx. 1 - cartilaginous skeleton, 2 - proc. extensorius, 3 - continuous lines of endochondral ossification of the phalanx corpus, 4 - intertrabecular space, 5 - blood vessel, 6 - osteogenous periosteum. HE, magn. $10 \times 10$

Fig. 8: Foetus, CRL $210 \mathrm{~mm}$, detail of apex phalangis distalis. 1 - desmogenous ossification of the apex, 2 - osteogenous periosteum, 3 - corium, 4 - surface lamella with trabeculae, 5 - broad intertrabecular space, 6 - blood vessels. $\mathrm{HE}, 4 \times 10$ 
Plate II.
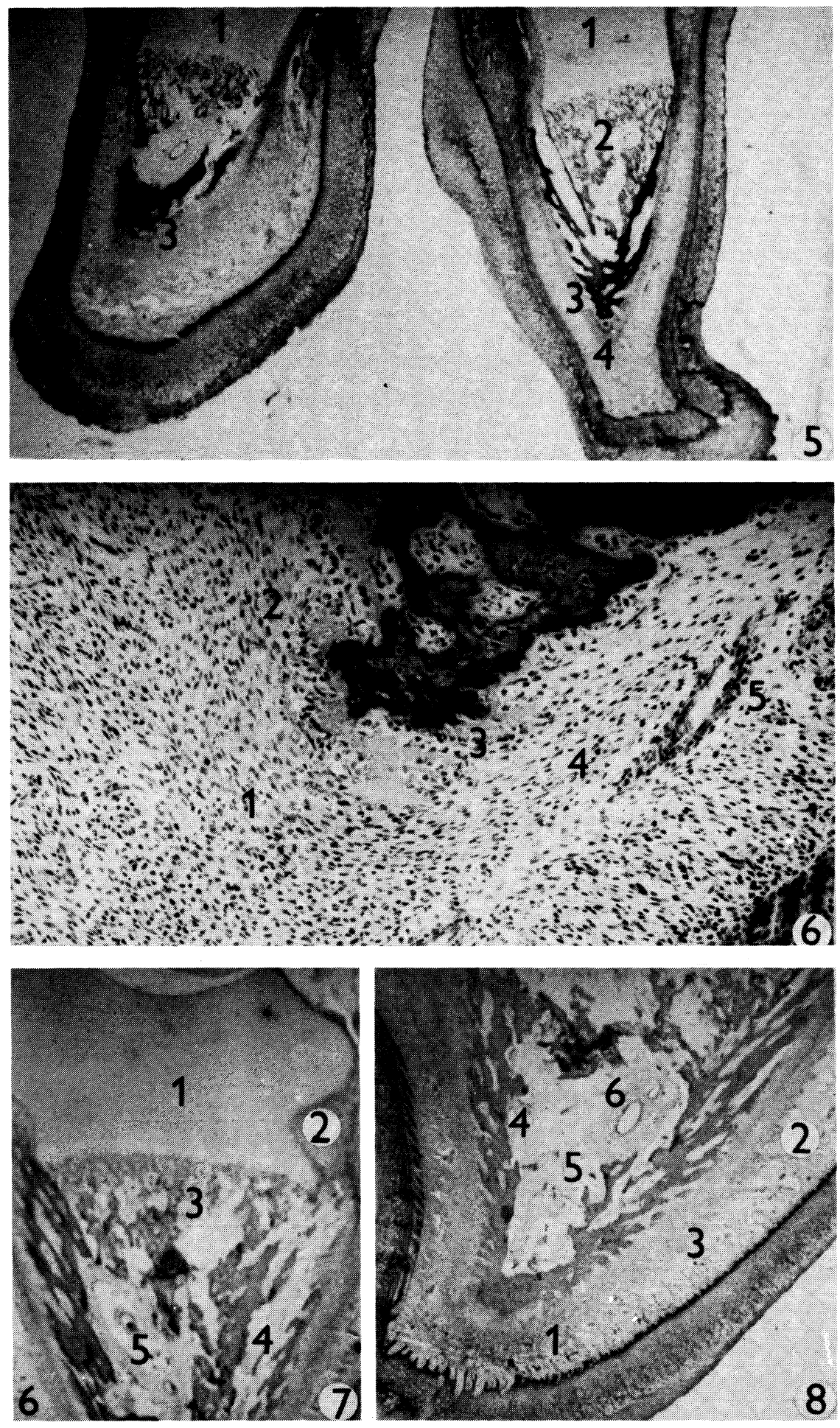
Plate III.

Fig. 9: Foetus, CRL $70 \mathrm{~mm}$, apperance of primary ossification of the diaphysis of the middle phalanx. 1 - middle phalanx cartilage, 2 - primary ossification centre on the axial side of cartilaginous skeleton, 3 - metachromasia of the basic cartilaginous material, 4 - hypertrophic chondrocytes, 5 - perichodrium. Alcian blue - Ponceau $2 \mathrm{R}$ with acid fuchsine, magn. $20 \times 10$

Fig. 10: Foetus, CRL $75 \mathrm{~mm}$. Ossification of the middle phalanx corpus. 1 - cartilaginous capitulum of the proximal phalanx, 2 - skeleton of the middle phalanx, 3 - endochondral ossification progressing abaxially, 4 - newly appearing osteogenous canals in the phalanx skeleton. HE, magn. $4 \times 10$

Fig. 11: Foetus, CRL $70 \mathrm{~mm}$, detail of periosteal ossification of the middle phalanx. 1 - perichondrium, 2 - osteogenous periosteum layer, 3 - beginning of cortical lamella of compact bone, 4 - hypertrophic cartilage, 5 - ossiformous zone of endochondral ossification. HE, magn. 10×10

Plate IV.

Fig. 12: Foetus, CRL $210 \mathrm{~mm}$, ossification of the corpus of proximal and middle phalanges. 1 - beams of the spongious bone of the diaphysis, 2 - epiphysis of the middle phalanx, 3 - lamella of the compact bone of the proximal phalanx corpus, 4 - capitulum of the proximal phalanx, 5 - spongious bone of the middle phalanx corpus, 6,7 - primary medullar cavity, 8 - osteogenous canals of the middle phalanx epiphysis, 9 - capitulum of the middle phalanx. Alcian blue - Ponceau $2 \mathrm{R}$ with acid fuchsine, magn. $6.3 \times 2$

Fig. 13: Foetus, CRL $210 \mathrm{~mm}$. Detail of the capitulum of the proximal phalanx. 1 - capitulum, 2 - epiphysis of the middle phalanx, 3 - articular cavity of the proximal joint of the digit, 4 - penetrating blood vessel, 5 - osteogenous canal with a blood vessel and pericapillary osteogenous cells, 6 - spongious bone of the diaphysis, 7 - primary medullar cavity with medullar vessels. Alcian blue - Ponceau $2 \mathrm{R}$ with acid fuchsine, magn. 17.5×2

\section{Plate V.}

Fig. 14. Foetus, CRL $210 \mathrm{~mm}$. Ossification of the proximal phalanx. 1 - epiphysis, 2 -spongious bone of the diaphysis, 3 - capitulum, 4 - surface lamella of compact bone of the diaphysis, 5 - primary medullar cavity filled with mesenchymal blastema. Alcian blue - Ponceau $2 \mathrm{R}$ with acid fuchsine, magn. $6.3 \times 2$

Fig. 15: Foetus, CRL $210 \mathrm{~mm}$. Endochondral ossification of the diaphysis of the proximal phalanx. 1 - growing cartilage zone, 2 - hypertrophic cartilage zone, 3 - blood vessels with transchondral behaviour, 4 - erosion line, 5 - osteoid zone of ossificatoin. Alcian blue - Ponceau $2 \mathrm{R}$ with acid fuchsine, magn. $32 \times 2$

Figs. 12-15 were made at the Anatomical Institute of the University of Veterinary Science in Hannover using macroscope WILD M 420 with an automatic camera WILD MPS 45 
Plate III.
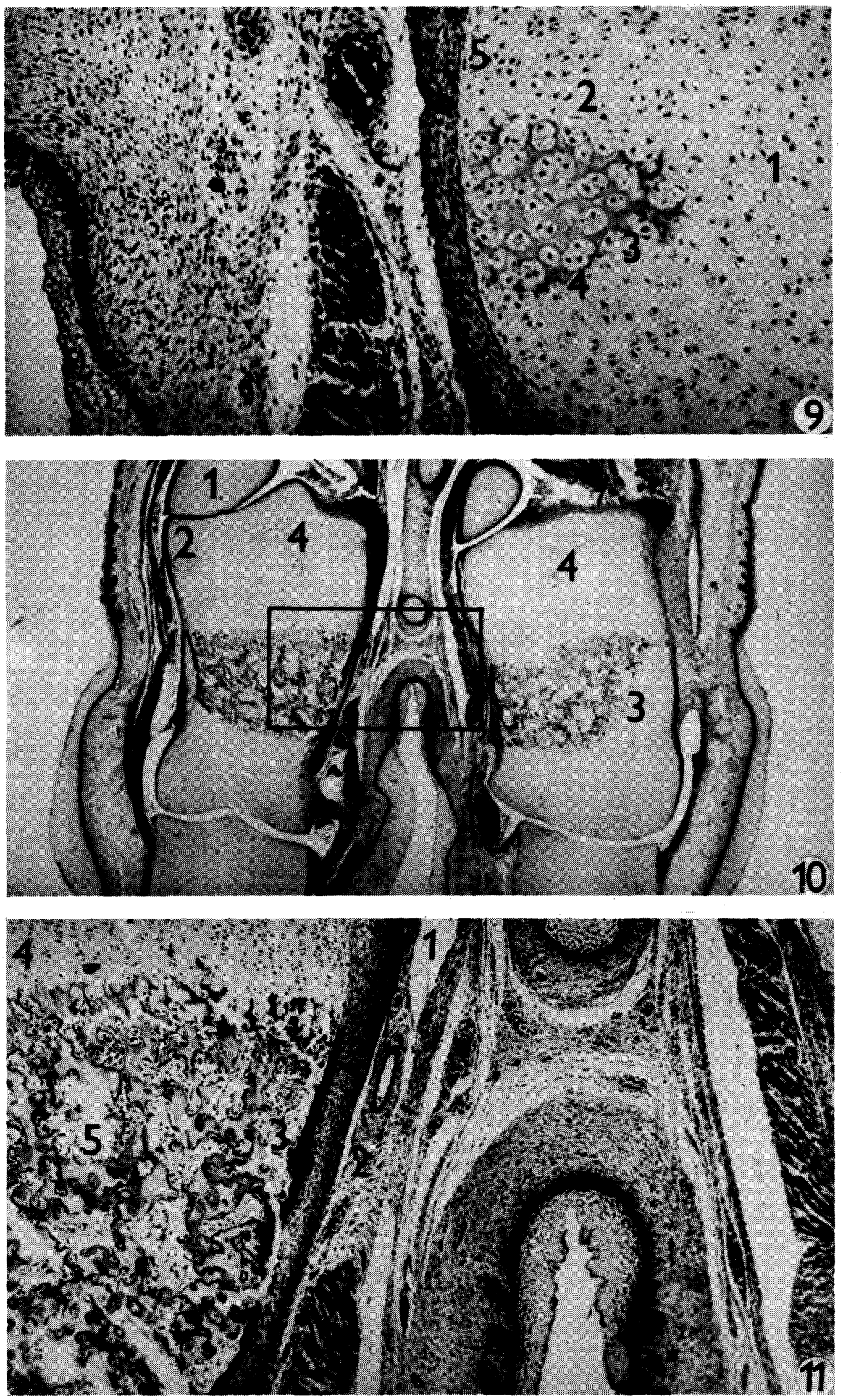


\section{Plate IV.}
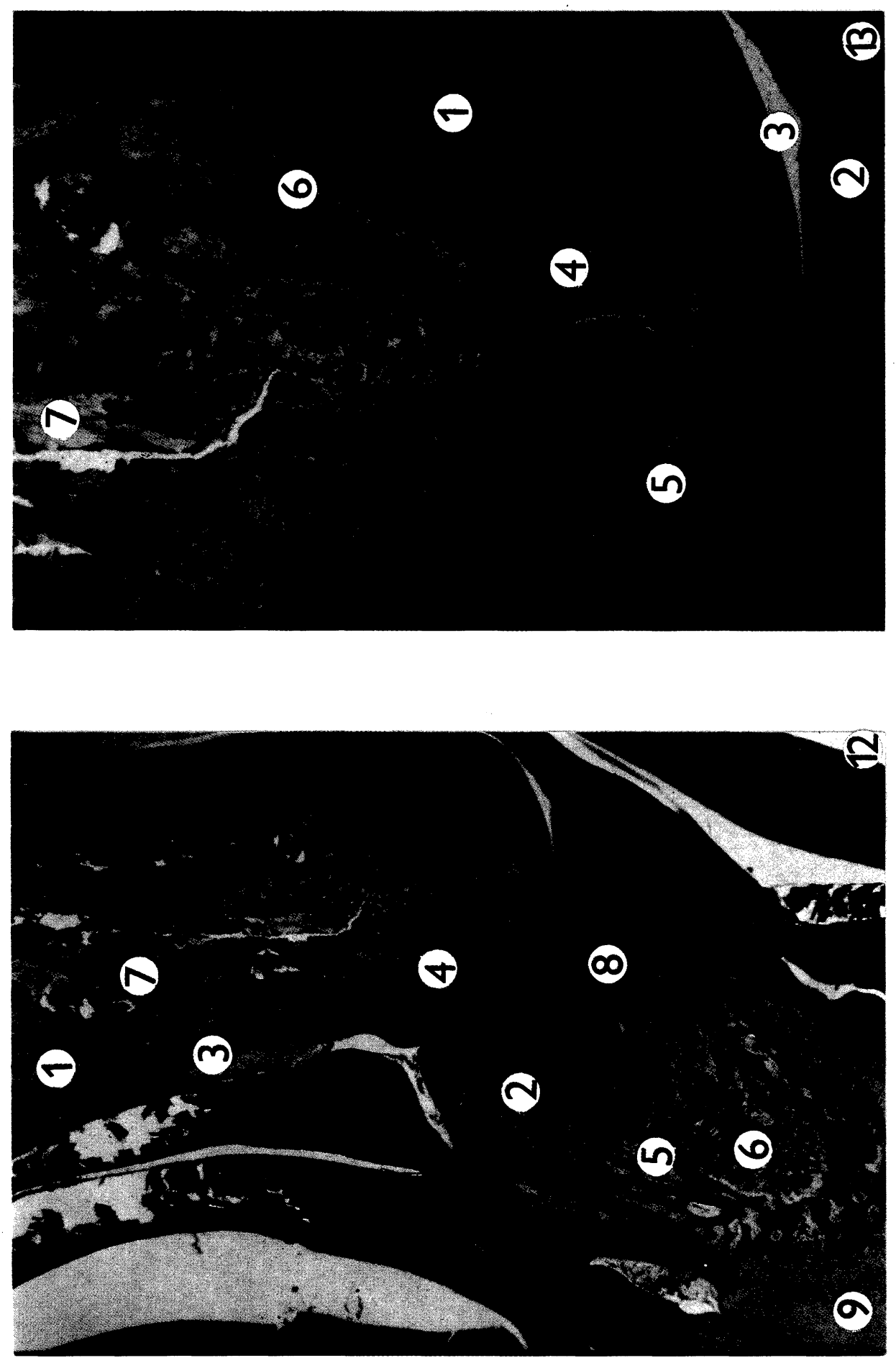
Plate V.

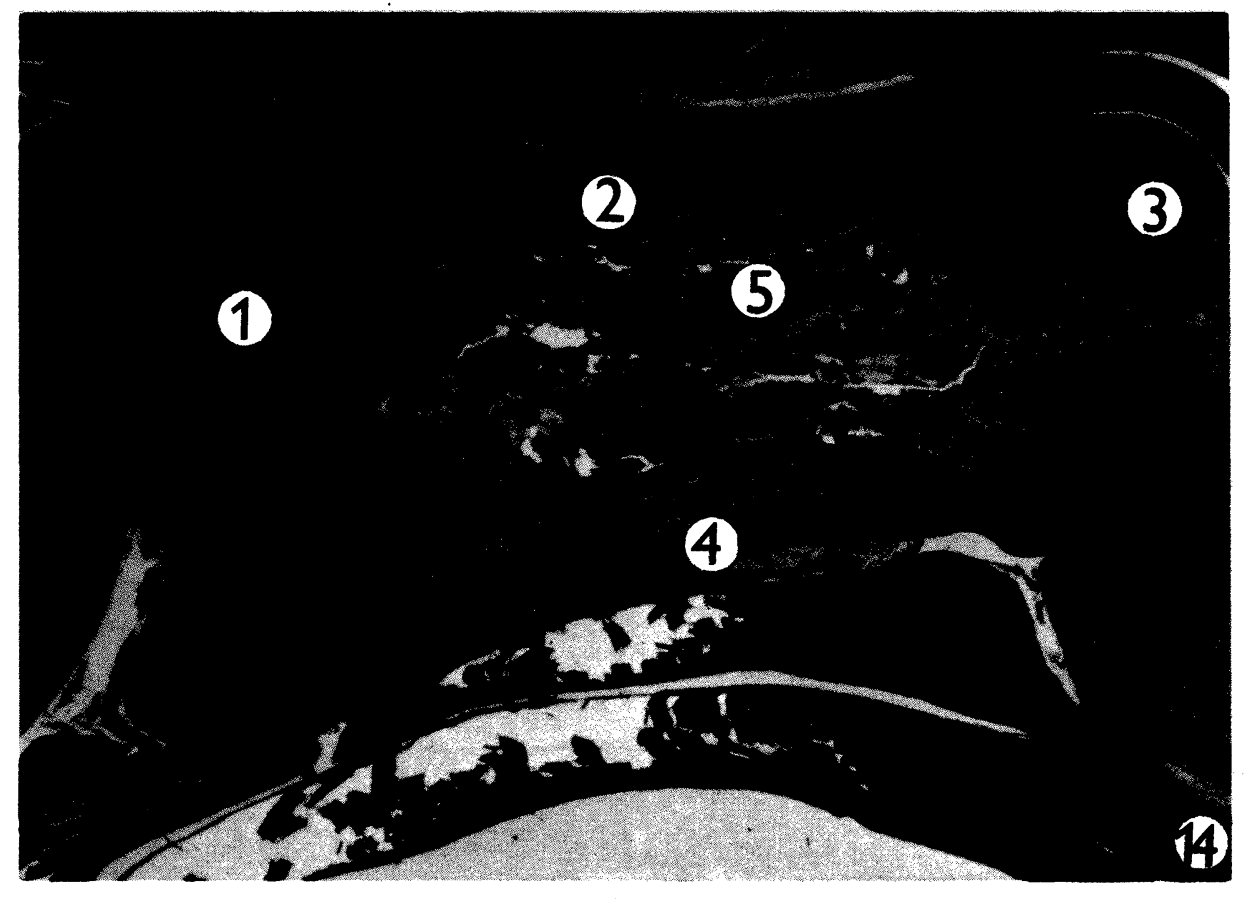

(3)

(1)

(3)

$(4)$

(2)

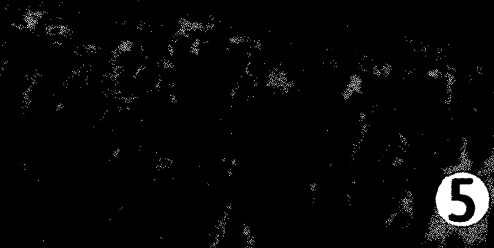

5 